\title{
Commemorating Dr. Gudmundur "Bo" Bodvarsson (1951-2006), a Leader of the Deep Unsaturated Flow and Transport Investigations
}

\author{
Chin-Fu Tsang ${ }^{1}$, Marcelo Lippmann ${ }^{1}$, Patrick Dobson ${ }^{1}$, Yvonne Tsang ${ }^{1}$, Boris Faybishenko ${ }^{1, *}$, \\ Sally Benson ${ }^{2}$, Jens Birkholzer ${ }^{1}$, Stefan Finsterle ${ }^{1}$, Daniel Hawkes ${ }^{1}$, Susan Hubbard ${ }^{1}$, \\ Timothy Kneafsey ${ }^{1}$, Hui-Hai Liu ${ }^{3}$, Curtis M. Oldenburg ${ }^{1}$, Karsten Pruess ${ }^{1}$, Eric Sonnenthal ${ }^{1}$, \\ Maryann Villavert ${ }^{1}$, Joseph Wang ${ }^{1}$, Yu-Shu Wu ${ }^{4}$ and Robert W. Zimmerman ${ }^{5}$ \\ 1 Lawrence Berkeley National Laboratory, 1 Cyclotron Road, Berkeley, CA 94720, USA; \\ cftsang@lbl.gov (C.-F.T.); mjlippmann@lbl.gov (M.L.); pfdobson@lbl.gov (P.D.); yttsang@lbl.gov (Y.T.); \\ jtbirkholzer@lbl.gov (J.B.); safinsterle@lbl.gov (S.F.); dshawkes44@aol.com (D.H.); sshubbard@lbl.gov (S.H.); \\ tjkneafsey@lbl.gov (T.K.); cmoldenburg@lbl.gov (C.M.O.); k_pruess@lbl.gov (K.P.); \\ elsonnenthal@lbl.gov (E.S.); mvillavert@lbl.gov (M.V.); jswang@lbl.gov (J.W.) \\ 2 Department of Energy Resources Engineering, Stanford University, Stanford, CA 94305, USA; \\ smbenson@stanford.edu \\ 3 Aramco Research Center, 16300 Park Row, Houston, TX 77084, USA; Hui-Hai.Liu@aramcoservices.com \\ 4 Department of Petroleum Engineering, Colorado School of Mines, 1500 Illinois St., Golden, CO 80401, USA; \\ ywu@mines.edu \\ 5 Department of Earth Science and Engineering, Imperial College, London, SW7 2BP, UK; \\ r.w.zimmerman@imperial.ac.uk \\ * Correspondence: bafaybishenko@lbl.gov
}

Received: 8 November 2017; Accepted: 22 November 2017; Published: 30 December 2017

The Special Issue "Water and Solute Transport in Vadose Zone" in the journal Water is dedicated to the memory of Dr. Gudmundur "Bo" Bodvarsson, the former director of the Earth Sciences Division of Lawrence Berkeley National Laboratory (http:/ / eesa.lbl.gov/profiles/gudmundur-bo-sbodvarsson/).

The hydrologic community lost one of its prominent leaders with the death of Gudmundur (Bo) Bodvarsson in 2006. We knew Bo as a friend and colleague for many years. His untimely death was a shock, considering his age (only 54), his intense research activity at the time, and his love of life. His enthusiasm was boundless. Not only was he passionate to learn everything about the earth sciences, he was passionate about everything, period! He played all kinds of sports - especially beach volleyball — at the highest competitive level. His energy and intensity were relentless, and never diminished.

Bo had a distinguished career at Berkeley since earning his PhD in hydrogeology under the supervision of Paul Witherspoon at UC Berkeley in 1981. From that time until 2006, he spent his entire professional career within the Earth Sciences Division of the Lawrence Berkeley National Laboratory, rising through the ranks until he was appointed Division Director in 2001.

His research may be divided into two time periods, with each period focusing on one area of geoscientific research. Bo's research in the first period was focused on geothermal reservoir evaluation and exploitation. His research in the second period was focused on site characterization and performance assessment of a potential nuclear waste repository at Yucca Mountain. Both areas of research had, and still have, significant relevance to major problems of concern to society. In both areas, Bo had made outstanding contributions.

His research can be characterized by two words: intensive and comprehensive. The range of geothermal fields that Bo studied, and on which he published many papers in peer reviewed journals, 
is truly amazing. They include the Cerro Prieto geothermal field in Mexico, the Baca geothermal field in New Mexico, the East Olkaria geothermal field in Kenya, the Ahuachapan geothermal field in El Salvador, the Palinpinon geothermal field in the Philippines, the Geysers geothermal field in California, and the Nesjavellir, Svartsengi, and Krafla geothermal fields in his native Iceland. These site-specific studies were in addition to his major contributions to key fundamental geothermal topics, such as two-phase convective flow, thermal flow in fractured-porous reservoir systems, and nonisothermal well test methods in geothermal reservoirs. For example, we refer to the set of four papers published in Water Resources Research in 1984 on the Krafla geothermal field in Iceland. These papers emphasized, respectively, analysis of well test data, the natural state of the reservoir, the generation capacity of the field, and history matching and prediction of individual well performance. They clearly demonstrated the comprehensiveness of Bo's research style.

Starting in the late 1980s, Bo began to turn his attention to the problem of site characterization and performance assessment of the proposed nuclear waste repository at Yucca Mountain. The main barrier to potential radionuclide leakage from such a repository is the unsaturated zone, or the vadose zone, consisting mainly of fractured tuff, which separates the repository from the saturated zone. This was the area that Bo decided to direct his considerable research energy and skills. He and his group at Berkeley Lab studied various key issues related to field investigations and modeling of flow and transport in the vadose zone, such as the active fracture model for unsaturated flow and transport, subsurface pneumatic responses, heating experiments, perched water phenomena, and upscaling and parameterization of flow and transport models. Each of these studies was, and is, a significant contribution to the field.

In the middle of all these studies, Bo saw the need to build a 3D site-scale flow model of the unsaturated zone at Yucca Mountain. In his characteristically intense and persistent style, he pushed this forward, through a series of model versions, into a very useful framework, not only for performance assessment of a nuclear waste repository, but also for evaluating alternative modeling approaches to explore the impacts of heterogeneity, and for the design of field experiments to address various technical issues for model calibration and prediction. It was in recognition of his important role and multiple contributions to the U.S. Department of Energy's Yucca Mountain Project that he was designated as the Head of the Department of Unsaturated Zone Scientific Studies within the Yucca Mountain project, from 1997 to his death in 2006.

Bo was a demanding yet supportive leader. He always found time to talk to people face-to-face, whether it was walking the halls and running into people, or extending an invitation to attend holiday parties, picnics, and sporting events, or celebrating milestones that the group had achieved. His ability to build morale and bring out the best in people inspired those around him to work harder. His organizational skill enabled his multidisciplinary team to deliver high-quality models in a timely manner for the proposed Yucca Mountain high-level radioactive waste repository, and made Berkeley Lab a recognized leader in this challenging Department of Energy project. He had an admirable ability to identify the key aspects of a problem, to develop potential solutions, and to lead the efforts to solve problems over time.

When Paul A. Witherspoon (1919-2012), his professor and mentor at UC Berkeley, learned of Bo's passing, he said, "Bo was a gifted individual and one of the hardest working graduate students I ever had. He carried this approach with him while pursuing his career at the Lab and developed into a disciplined scientist. No problem in his field was too tough for him to handle. The growth and success of the Earth Sciences Division stands as a tribute to his remarkable abilities".

We value the various contributions to this Special Issue of the journal Water, as a recognition of the impact of Bo in this research field, and as an appreciation of his enthusiasm and drive, which rubbed off on everyone who worked with him over the years. 
Acknowledgments: This manuscript has been authored by authors at Lawrence Berkeley National Laboratory under Contract No. DE-AC02-05CH11231 with the U.S. Department of Energy. The U.S. Government retains, and the publisher, by accepting the article for publication, acknowledges, that the U.S. Government retains a non-exclusive, paid-up, irrevocable, world-wide license to publish or reproduce the published form of this manuscript, or allow others to do so, for U.S. Government purposes.

Conflicts of Interest: The authors declare no conflict of interest.

(C) 2017 by the authors. Licensee MDPI, Basel, Switzerland. This article is an open access article distributed under the terms and conditions of the Creative Commons Attribution (CC BY) license (http://creativecommons.org/licenses/by/4.0/). 